\author{
Alicja Markiewicz \\ Uniwersytet Łódzki (Łódź, Polska)
}

\title{
Twórcze wykorzystanie stereotypu a językowa wizja świata ${ }^{1}$
}

Stereotyp językowy czy też semantyczny określa się jako zwerbalizowane przekonanie na temat osoby, obiektu czy też zjawiska, przypisujące tym osobom, obiektom czy zjawiskom pewne właściwości czy też cechy. Zwraca się uwagę, że tak rozumiany stereotyp, czyli swego rodzaju sąd wartościujący czy aksjologiczny, jest utrwalony w strukturze języka, zakrzepły w nim, a w konsekwencji odporny na zmiany oraz nieweryfikowalny. Nieweryfikowalność tego sądu stanowi rezultatu faktu, że jest on uogólnieniem, generalizacją, której treść odnosi się do wszystkich obiektów danej klasy. Stereotypowy sposób postrzegania kotów można określić jako przekonanie głoszące chociażby, że „koty to zwierzęta domowe, cechujące się niezależnością". Co jednak istotne, tego rodzaju pogląd na temat kotów obejmuje swoją treścią wszystkie koty bez wyjątku, co sprawia, że takiego sądu niepodobna zweryfikować (por.: Bartmiński 2007: 53-71).

Warto jednakże podkreślić, że nie wszyscy badacze postrzegają stereotyp jako sąd wartościujący na temat osób, obiektów, zjawisk etc., stanowiący naddatek dla znaczenia danych wyrażeń językowych oraz dlań nieistotny. Amerykański filozof Hilary Putnam w swoim artykule Znaczenie wyrazu 'znaczenie' rozwijając eksternalistyczną teorię znaczenia, twierdzi, że znaczenie nazw własnych czy też nazw odnoszących się do rodzajów naturalnych uzależnione jest od tego, co wobec jednostek zewnętrzne (natura bytów, praktyka językowa danej wspólnoty). Putnam postrzega stereotyp jako jedną ze składowych dla znaczenia danych terminów.

[Stereotyp - A. M.] jest tradycyjnym (często fałszywym) wyobrażeniem (które może być $\mathrm{z}$ gruntu nietrafne) na temat tego, jak wygląda, lub jak działa, lub czym jest $X$. (...). Twierdzę, że z wyrazami „tygrys”, „złoto” itd. Wiążą się takie właśnie tradycyjne wyobrażenia, $\mathrm{i}$ - ponadto - że to twierdzenie stanowi jedyne ziarno prawdy w teorii ,pojęć".

Treść artykułu stanowi rozwinięcie wniosków zawartych przez autorkę w pracy magisterskiej Językowa kreacja społecznej wizji świata w felietonach Macieja Nowaka z Krytyki Politycznej, napisanej pod kierunkiem prof. nadzw. dr hab. Barbary Kudry w Katedrze Dziennikarstwa i Komunikacji Społecznej Uniwersytetu Łódzkiego. 
Zgodnie z powyższym poglądem od osoby, która wie, co to znaczy „tygrys” (...) wymaga się, by wiedziała, że stereotypowe tygrysy są pręgowane. (...) Stereotyp tygrysa musi obejmować pręgi, jeżeli mamy uważać, że został skutecznie przyswojony (...). Fakt, że stereotyp związany z wyrazem $X$ obejmuje określoną cechę (np. pręgi), nie oznacza, że jest prawdą analityczną, iż wszystkie $X y$ mają tę cechę, ani że większość Xów ma tę cechę, ani że wszystkie normalne $X y$ mają tę cechę, ani że pewne $X y$ mają tę cechę. (...) (Putnam 1998: 148-9).

Ujmując pojęcie stereotypu w sposób pozytywny należy stwierdzić, że stanowi on istotną część znaczeń wyrażeń językowych, jest jedną ze składowych tych znaczeń, czy innymi słowy, jest jednym z elementów znaczenia poszczególnych nazw przedmiotów czy też zjawisk. Negatywne ujęcie tego pojęcia każe podkreślić, że stereotyp nie stanowi swego rodzaju naddatku semantycznego dla pewnych wyrażeń językowych, elementu dodatkowego, nieistotnego dla znaczeń tych wyrażeń.

Tego rodzaju sposób ujmowania stereotypu stanowi rezultat eksternalistycznej teorii znaczenia ${ }^{2}$ nazw własnych oraz nazw rodzajów naturalnych, opracowanej przez Hilary’ego Putnama. Zwrócił on uwagę na intersubiektywny charakter znaczeń wyrażeń językowych, przełamując tym samym, królujące w ówczesnej filozofii języka, przekonanie, że znaczenia wyrażeń językowych uzależnione są od tego, co wobec jednostki wewnętrzne, czyli jej umysł, świadomość, indywidualny stan psychiczny etc. Putnam, za pomocą przeprowadzonego eksperymentu myślowego z Ziemią Bliźniaczą, podjął próbę udowodnienia, że znaczenia nazw własnych, a także nazw rodzajów naturalnych, uzależnione są od tego, co wobec podmiotów zewnętrzne - środowiska naturalnego czy też natury przedmiotów, a także od praktyki językowej danej społeczności. Znaczenie nazwy ,woda” zdeterminowane jest przez skład chemiczny tej substancji, czyli $\mathrm{H}_{2} \mathrm{O}$, nie natomiast przez zbiór przekonań, poglądów, wyobrażeń etc. na temat wody bądź też przez określony stan psychiczny, w którym znajduje się podmiot. Putnam, opierając swoją teorię znaczenia na przekonaniu o intersubiektywnym charakterze znaczeń wyrażeń językowych, podkreśla, że użytkownicy języka nie muszą posiadać wiedzy na temat natury wszystkich realnie istniejących obiektów czy zjawisk, by móc prawidłowo odnosić się do tych przedmiotów. Istotne, by dana część społeczności językowej posiadała tego rodzaju wiedzę. Putnam wprowadził więc hipotezę

W Oksfordzkim Słowniku Filozoficznym eksternalizm został określony w sposób następujący: „W filozofii umysłu i języka doktryna głosząca, iż to, co się myśli, mówi czy przeżywa, jest zasadniczo zależne od zewnętrznych względem umysłu aspektów świata. Eksternalizm nie ogranicza się do twierdzenia, że takie stany psychiczne są z reguły wywoływane przez czynniki zewnętrzne, ale podkreśla, iż nie mogłyby istnieć w takiej postaci, w jakiej istnieją, gdyby człowiek nie był zanurzony w określonego typu świecie zewnętrznym, w czym przeciwstawia się kartezjańskiemu oddzieleniu psychiki od świata fizycznego. Za istotne determinanty treści psychiki uważa rozmaite czynniki zewnętrzne, w tym zachowania ekspertów, normy językowe danej społeczności oraz ogólne uwikłanie przyczynowe podmiotu (...) (Szczubiałka 1997: 104-105). 
podziału pracy językowej, która zakłada, że w społeczności znajdują się eksperci, posiadający umiejętność określenia, czy dana nazwa, oznaczająca rodzaj naturalny (na przykład nazwa: „woda”, „tygrys”, ,złoto”) odnosi się bądź powinna odnosić się do konkretnego obiektu czy zjawiska. Od poszczególnych użytkowników języka wymaga się natomiast, by posiadali indywidualna kompetencję językowa, która zdefiniowana jest w sposób następujący:

Kowalski musi mieć jakieś konkretne myśli i umiejętności związane z $W$, ażeby mógł wypełniać swoje zadania w ramach podziału pracy językowej (Putnam 1998: 143).

Znajomość stereotypów, związanych z pewnymi terminami, jest więc niezbędna oraz konieczna, by móc w sposób prawidłowy odnosić się do obiektów, zjawisk, osób, a także w celu osiągania różnego rodzaju celów komunikacyjnych. Stereotyp, jako jeden ze składników znaczenia, umożliwia użytkownikom języka wzajemnie się rozumieć, odnosić do tego, co wobec nich zewnętrzne, percypować oraz kategoryzować rzeczywistość etc.

Zgodnie z ujęciem, zaproponowanym przez Putnama, można stwierdzić, że stereotyp pełni przede wszystkim funkcję integrującą daną wspólnotę językową, społeczną, komunikacyjną oraz poznawczą, a nie - jak zwraca uwagę liczne grono badaczy - wartościującą, ideologiotwórczą czy też polityczną. Biorąc pod uwagę stereotyp związany z terminem „złoto”, który można by w sposób skrótowy scharakteryzować jako „metal szlachetny, symbol luksusu i bogactwa, rzecz o wysokiej wartości”, należy stwierdzić, że stereotyp ten wpływa nie tylko na wzajemne zrozumienie jednostek, posługujących się tym terminem, ale również na możliwość kreowania swoistej wizji świata przez daną jednostkę.

Sformułowanie językowa kreacja wizji świata wskazuje, że dany podmiot, użytkownik języka, posiadający odpowiednie kompetencje językowe, czyli innymi słowy, posiadający umiejętność wykorzystywania, operowania językiem w sposób twórczy, posiada zdolność prezentowania, a także tworzenia, pewnego indywidualnego obrazu świata czy rzeczywistości. Stanowi to rezultat przekonania, że za pomocą języka (poprzez użycie specyficznych struktur gramatycznych, wykorzystanie różnego rodzaju środków językowych takich jak: metafory, metonimie, aluzje etc.) użytkownik języka posiada zdolność, żeby w sposób pośredni oddziaływać na otoczenie fizykalne.

Tego rodzaju tezy zdają się być zgodne z koncepcją Językowego Obrazu Świata, która współcześnie jest jedną z najbardziej znaczących teorii w kognitywnie zorientowanym językoznawstwie. Jak jednak wskazuje Janusz Anusiewicz w artykule Problematyka JOS w pogladach niektórych językoznawców i filozofów niemieckich $X X$ wieku, koncepcja Językowego Obrazu Świata została ukształtowana przez dwudziestowiecznych badaczy takich jak: Wilhelm von Humboldt, Leo Weisgerber czy też Helmut Gipper. Asumpt do stworzenia tejże koncepcji stanowiło spostrzeżenie, że język ma procesualny, dynamiczny charakter, a jego 
struktura nieustannie się zmienia. Co jednak istotne, nie pozbawiali oni języka stałego korzenia czy też niezmiennego jądra - była nim gramatyka danego języka. Co ważne, zgodnie z ujęciem tych filozofów, język przechowuje całokształt wiedzy, przekonań, norm oraz wartości, a tym samym, wpływa na sposób postrzegania rzeczywistości przez jednostki, kształtuje ich doświadczenia etc. (zob.: Anusiewicz 1999: 269-81).

Koncepcja Językowego Obrazu Świata jest rozwijana przede wszystkim przez takich badaczy jak: Jolanta Maćkiewicz, Jerzy Bartmiński, Renata Grzegorczykowa, i innych. Renata Grzegorczykowa, opisując Językowy Obraz Świata, twierdzi, że każdy z języków naturalnych posiada charakterystyczny dlań sposób postrzegania świata, co przejawia się w swego rodzaju siatce pojęciowej, umożliwiającej jednostkom percypowanie rzeczywistości, kategoryzowanie jej, opisywanie, a w konsekwencji doświadczanie. Jak pisze:

[JOS stanowi - A. M.] (...) strukturę pojęciową utrwaloną (zakrzepłą) w systemie danego języka, czyli w jego właściwościach gramatycznych i leksykalnych (znaczeniach wyrazów i ich łączliwości) realizującą się w języku, za pomocą tekstów (wypowiedzi). (Grzegorczykowa 1999: 41).

Jerzy Bartmiński w artykule O pojęciu językowego obrazu świata twierdzi natomiast, że Językowy Obraz Świata:

(...) jest zawartą w języku, różnie zwerbalizowaną interpretacją rzeczywistości dającą się ująć w postaci zespołu sądów o świecie. Mogą to być sądy „utrwalone”, czyli mające oparcie w samej materii języka, a więc w gramatyce, słownictwie, w kliszowanych tekstach (np. przysłowiach), ale także sądy presuponowane, tj. implikowane przez formy językowe, utrwalone na poziomie społecznej wiedzy, przekonań, mitów i rytuałów (Bartmiński 1999: 12).

Zarówno Renata Grzegorczykowa, jak i Jerzy Bartmiński zwracają uwagę na fakt, iż język przechowuje system norm, wartości, przekonań, wypracowanych przez daną społeczność językową. Dzięki temu dana wspólnota interpretuje rzeczywistość, ujmuje ją w konkretne ramy oraz nadaje jej znaczenie, co z kolei stanowi gwarancję efektywnej komunikacji międzyludzkiej, a także poczucia wspólnotowości, integracji, możliwości wymiany danych doświadczeń. Co istotne, Jolanta Maćkiewicz w swoim artykule Wyspa-językowy obraz wycinka rzeczywistości, referuje, w jaki sposób możliwe jest zrekonstruowanie danego językowego obrazu świata. Uczona twierdzi, że konieczne jest chociażby zbadanie etymologii danego wyrazu, jego znaczenia, prześledzenie frazeologizmów oraz przysłów, w jakich występuje.

Można zaryzykować twierdzenie, że stereotyp stanowi jeden z fundamentów językowego obrazu świata - jest on nośnikiem powszechnie żywionych wyobrażeń na temat pewnych obiektów oznaczanych za pomocą konkretnych terminów, 
zdaje relację z wartości przypisywanych tym przedmiotom czy zjawiskom, a także wskazuje na idee zawarte w znaczeniu danego terminu. Można twierdzić więc, że stereotyp ugruntowuje, konstytuuje pewien obraz świata, sposób postrzegania przedmiotów, osób, zjawisk, których dotyczy stereotyp.

W tym miejscu należy jednak przypomnieć o dystynkcji poczynionej przez Jerzego Bartmińskiego na przedmiotowy oraz podmiotowy językowy obraz świata. Pierwszy z wymienionych odnosi się do obrazu rzeczywistości, zakrzepłego w strukturze danego języka naturalnego oraz jest zgodny z wyżej poczynionymi spostrzeżeniami. Podmiotowy językowy obraz świata to innymi słowy indywidualna, subiektywna wizja świata, rzeczywistości. Odnosi się on do prezentacji autorskiej, twórczej, nieskonwencjonalizowanej, nieznajdującej oparcia w strukturze języka, wizji czy też sposobu postrzegania otaczającej rzeczywistości; jest swego rodzaju indywidualną kategoryzacją rzeczywistości. Podmiotowy językowy obraz świata wymaga od użytkownika języka kreatywności językowej, umiejętności efektywnego wykorzystywania dostępnych w języku środków językowych, a także - jak się wydaje - umiejętności stosowania perswazyjnych środków językowych.

Rozróżnienie to zwraca uwagę na pewnego rodzaju paradoks - stereotyp, przechowując określony system norm, wartości, idei, poglądów, konstytuuje przedmiotowy językowy obraz świata, wykorzystywany jednak przez twórczego użytkownika języka, potrafiącego w sposób umiejętny operować językiem, staje się bazą dla prezentowania autorskiej wizji świata, czyli podmiotowego językowego obrazu świata. Co istotne, ten wykreowany, indywidualny językowy opis sposobu postrzegania rzeczywistości może w konsekwencji zaprzeczać, zastygłemu w strukturze języka, językowemu obrazowi świata.

Sądzę, że do twórczych sposób wykorzystywania stereotypu można zaliczyć $^{3}$. Po pierwsze, zaprzeczenie stereotypowi, na przykład:

Moja babcia Leokadia, przedwojenna nauczycielka matematyki, była typową przedstawicielką polskiej głupio-mądrej inteligencji. Skupiona na sprawdzaniu klasówek i oddawaniu się dewocji jakoś nie dostrzegła w porę powagi wydarzeń sierpniowych sprzed ponad 30 lat. (Nowak 2011a: 1).

Cytat ten można odnaleźć w felietonie Macieja Nowaka, zatytułowanym Babci Lodzi to nie obchodzi. Na łamach internetowego wydania Krytyki Politycznej ukazał się on 5 lipca 2011 roku. Maciej Nowak wykorzystuje stereotyp związany z terminem ,przedwojenny nauczyciel”. Stereotyp ten przypisuje obiektom należącym do tej klasy takie cechy jak: inteligencja, mądrość, bystrość umysłu etc. W sposób jawny zaprzecza mu, pisząc, że osoby, do których odnosi się termin

Wskazane sposoby twórczego wykorzystania stereotypu stanowią rezultat badań nad sposobami językowej kreacji wizji świata, przeprowadzonych na felietonach Maciej Nowaka, opublikowanych na łamach Krytyki Politycznej w 2011 roku. 
„przedwojenny nauczyciel” charakteryzują się cechami odwrotnymi, czyli wąskimi horyzontami myślowymi.

Po drugie, wykorzystanie stereotypu jako przesłanki w celu przeprowadzenia argumentacji, której wniosek będzie absurdalny, na przykład:

Po ponad dekadzie łatwo już zauważyć, że praca w reklamie realizuje odwieczną misję aktora, czyli ucieleśnianie zbiorowych snów i marzeń. A gdzie bardziej precyzyjnie odbijają się aspiracje społeczeństwa konsumpcyjnego, jak nie w reklamówkach? Furda z dylematami bohaterów antycznych, egzaltacją Hamletów i Konradów czy rozjechanymi postaciami Sary Kane. Skoro staliśmy się już wspólnotą klientów to czemu mieć pretensje do jej kapłanów, odprawiających rytualne podniesienia płynu do mycia naczyń albo szepczących zmysłowo nad inteligentnym kontem bankowym? (Nowak 2011b: 2).

Wykorzystując stereotyp związany z terminem ,aktor”, Maciej Nowak w felietonie Ja jako kostka rosolowa, wyciąga wniosek, że aktor wypełnia przypisywaną mu przez społeczeństwo misję poprzez udział w spotach reklamowych. Jest to wniosek nieco absurdalny. Zdaje się, że realizacja aktorskiej misji powinna polegać na udziale w ambitnych filmach czy też poprzez grę na deskach teatru.

Po trzecie, wyolbrzymienie, podkreślenie, swego rodzaju karykaturyzacja, stereotypu, na przykład: „A pedalstwo w kręgach futbolowej arystokracji to już problem poważny” (Nowak 2011c: 1), „ksenofobiczny nurt toruński” (Nowak 2011d: 1). Maciej Nowak za pomocą wyolbrzymienia stereotypu związanego z terminem ,pedalstwo” stara się wskazać niezasadność takiego sposobu postrzegania osób homoseksualnych, uproszczenie z tym związane oraz brak adekwatności cech przypisywanych osobom homoseksualnym. Wyolbrzymiając natomiast stereotyp związany z ks. Tadeuszem Rydzykiem (poprzez sformułowanie: „ksenofobiczny nurt toruński”) zdaje się podkreślać oraz zgadzać na tego rodzaju pogląd, sposób postrzegania tej osoby oraz jego zwolenników.

Warto w tym miejscu podkreślić, że estymacja sposobu twórczego wykorzystania stereotypu wymaga od odbiorcy wiedzy na temat poglądów osoby wykorzystującej kreatywnie stereotyp, umiejętności odszyfrowania ukrytego znaczenia, rekonstrukcji znaczenia intencjonalnego. Stąd też, należy zwrócić uwagę, że trzy - jak się wydaje podstawowe - sposoby twórczego wykorzystania stereotypu mają charakter ironiczny, a w konsekwencji charakter perswazyjny. Podobnie jak ironia, twórczy sposób wykorzystania stereotypu związany jest z pewnego rodzaju niedosłownością - autor nie prezentuje bezpośrednio swoich poglądów. Od odbiorców, co zostało wyżej wskazane, wymaga się wiedzy na temat przekonań osoby stosującej stereotyp, rozpoznania ironiczności danej wypowiedzi oraz zdekodowania niedosłownego znaczenia. Jak się wydaje, twórczy sposób wykorzystania stereotypu, stanowiąc ironiczny sposób użycia danego środka językowego, ma charakter perswazyjny. 
Wypowiadający ironię wykazuje się umiejętnością kontrolowania własnych emocji, podkreśla swoją racjonalność oraz zdroworozsądkowy sposób działania. Ironia zdaje się być postrzegana jako narzędzie wykorzystywane przez ludzi, cechujących się inteligencją, bystrością umysłu. Wpływa to na możliwość osiągnięcia czy realizacji celu perswazyjnego, bowiem wypowiadający ironię postrzegany jest jako swego rodzaju autorytet.

Inną istotną perswazyjną funkcję wypowiedzi ironicznych stanowi fakt, że ironia umożliwia niebezpośrednią deprecjację danego obiektu, zjawiska czy osoby. Wypowiadający ironię może uniknąć konsekwencji poprzez stwierdzenie, że wypowiedziany przez niego sąd na temat danej rzeczy posiadał jedynie znaczenie dosłowne, literalne, natomiast wskaźniki ironiczności wypowiedzi (takie jak: mimika, gestyka, intonacja) zostały mylnie przypisane mu przez audytorium. Ponadto, deprecjacja danego obiektu, zjawiska czy osoby za pomocą wypowiedzi ironicznej jest subtelniejsza, bardziej delikatna niż wykorzystanie w tym celu wypowiedzi w sposób dosłowny opisujący stan emocjonalny osądzającego; pozwala wypowiadającemu ironię uniknąć użycia wyrażeń wulgarnych, niestosownych, stricte agresywnych. W konsekwencji przekłada się to na sposób postrzegania wypowiadającego ironię przez jego audytorium - nie osądza ono go jako osoby pozbawionej kultury osobistej, nieprzestrzegającej obowiązującej w danej sytuacji konwencji, sposobu zachowania.

Należy także podkreślić, że ironia pełni funkcję perswazyjną, bowiem jest ona środkiem, który dla audytorium stanowi swego rodzaju zaskoczenie. Jest ona narzędziem niestandardowym, nieszablonowym, unikającym schematyzmu, a tym samym zwraca uwagę odbiorców, a przez to zapada w ich pamięć.

Istotny również wydaje się być fakt, że wypowiedź ironiczna wymaga od odbiorców odkodowania ukrytego w niej znaczenia, rozpoznania jej oraz odszyfrowania zawartego w niej sensu. Ten aspekt jednak zdaje się posiadać swoje pozytywne, jak i negatywne strony. Pozytywnym aspektem konieczności zrozumienia przez audytorium intencjonalnego znaczenia ironii jest możliwość zacieśniania społecznych więzi, budowania poczucia wspólnotowości, relacji społecznych. Odbiorcy, którzy rozpoznają ironię, zdają się utożsamiać z tezami, poglądami, głoszonymi przez wypowiadającego ironię. $Z$ drugiej jednak strony, istnieje ryzyko nierozpoznania ironii przez audytorium, a w konsekwencji przypisania tezom, wypowiadanym przez osobę ironizującą, znaczenia niezgodnego z jej intencją, co - ujmując innymi słowy - oznacza niepowodzenie komunikacyjne. Stosowanie ironii w celach perswazyjnych jest niezwykle ryzykowne. Osoba, mająca na celu przekonanie odbiorcy czy audytorium do swoich racji, przekonań, wartości, powinna wykorzystywać ironię w sposób przemyślany oraz dostosowany do grupy docelowej, uwzględniając jej światopogląd, wymagania oraz potrzeby.

Ironiczny, twórczy, sposób wykorzystania stereotypu pozwala kreować określoną wizję świata nie tylko ze względu na fakt, że ironia stanowi narzędzie językowe o charakterze perswazyjnym, ale również dlatego, że kreatywny sposób 
użycia stereotypu pozwala kreatorowi na prezentację własnych poglądów, przekonań, przedstawienie sposobu percypowania rzeczywistości w sposób zaskakujący odbiorcę. Audytorium, posiadające wiedzę na temat stereotypu, będącego jednym z konstytutywnych składników językowego obrazu świata, zwraca szczególną uwagę na niestandardowy sposób jego użycia.

Przezwyciężanie stereotypu poprzez jego twórcze wykorzystanie pełni funkcję edukacyjną, wychowawczą czy nawet etyczną, ponieważ tego rodzaju strategia demaskuje nie tylko stereotyp, ale również fakt, że nie opisuje on w sposób adekwatny wszystkich obiektów danej klasy. Podkreśla się uproszczenie, generalizację, schematyzm, na którym stereotyp bazuje, a w konsekwencji wskazuje się, że stereotyp - choć pełni funkcję poznawczą oraz jest znaczącym czynnikiem kształtującym doświadczenia - stanowi niesatysfakcjonujący sposób opisywania rzeczywistości, ignorujący złożoność oraz niejednorodność zjawisk, obiektów, osób. Z drugiej strony, co może wydawać się paradoksalne, twórcze wykorzystanie stereotypu podkreśla nieuchronność przeprowadzania upraszczającej kategoryzacji rzeczywistości, bowiem kategoryzacja tego rodzaju pozwala jednostkom na wzajemną komunikację oraz swobodne poruszanie się i percypowanie rzeczywistości.

\section{Bibliografia}

Anusiewicz J. (1999), Problematyka JOS w pogladach niektórych językoznawców i filozofów niemieckich XX wieku, [w:] Językowy obraz świata, red. J. Bartmiński, Lublin, s. 261-289.

Austin J. L. (1993), Mówienie i poznawanie: rozprawy i wyklady filozoficzne, Warszawa.

Bartmiński J. (1999), Stowo wstępne, [w:] Językowy obraz świata, red. J. Bartmiński, Lublin, s. $7-14$.

Bartmiński J. (2006), O pojęciu językowego obrazu świata, [w:] Językowe podstawy obrazu świata, Lublin, s. 11-21.

Bartmiński J. (2007), Stereotypy mieszkaja w języku. Studia etnolingwistyczne, Lublin, s. 53-111.

Bartmiński J., Niebrzegowska S., Nycz R. (2004), Punkt widzenia w tekście $i$ w dyskursie, Lublin.

Gibbs R. (2001), The Risk and Rewards of Ironic Communication, http://www.neurovr.org/emerging/book3/3CHAPT_08.PDF.

Grzegorczykowa R. (1999), Pojęcie językowego obrazu świata, [w:] Językowy obraz świata, red. J. Bartmiński, Lublin, s. 39-46.

Putnam H. (1998), Znaczenie wyrazu ,znaczenie”, [w:] H. Putnam, Wiele twarzy realizmu i inne eseje, Warszawa, s. 93-184.

Język, dyskurs, społeczeństwo: zwrot lingwistyczny w filozofii społecznej (2009), red. L. Rasiński, Warszawa.

Językowa kategoryzacja świata (1996), red. R. Grzegorczykowa, A. Pajdzińska, Lublin.

Maćkiewicz J. (1999), Wyspa - językowy obraz wycinka rzeczywistości, [w:] Językowy obraz świata, red. J. Bartmiński, Lublin, s. 47-56.

Nowak M. (2011a), Babci Lodzi to nie obchodzi, http://www.krytykapolityczna.pl/MaciejNowak/ BabciLodzitonieobchodzi/menuid-419.html.

Nowak M. (2011b), Ja jako kostka rosołowa, http://www.krytykapolityczna.pl/MaciejNowak/Jajakokostkarosolwa/menuid-350.html. 
Nowak M. (2011c), Kibice na szpilkach, http://www.krytykapolityczna.pl/MaciejNowak/Kibicenaszpilkach/menuid-27.html.

Nowak M. (2011d), Trupi zaduch, http://www.krytykapolityczna.p1/MaciejNowak/Trupizaduch/ menuid-27.html.

Punkt widzenia w języku i w kulturze (2004), red. J. Bartmiński, S. Niebrzegowska, R. Nycz, Lublin. Puzynina J. (1992), Język wartości, Warszawa.

Sperber D., Wilson D. (2003), Irony and the Use-Mention Distinction, http://www.ucl.ac.uk/ls/studypacks/Sperber-Ironyandtheuse.pdf.

Stewart C. (2013), Startegies of verbal irony in visual satire: Reading ,, The New Yorker 's ",Politics of Fear" cover, http://www.academia.edu/1171545/Strategies_of_Verbal_Irony_in_Visual_Satire_Reading_The_New_Yorkers_Politics_of_Fear_Cover.

Szczubiałka M. (1997), Hasło: Eksternalizm, [w:] red. J. Woleński, Oksfordzki słownik filozoficzny, Warszawa.

Wittgenstein L. (2000), Dociekania filozoficzne, Warszawa.

\title{
Alicja Markiewicz
}

\section{Creative Use of Stereotype and Linguistic View of the World}

\begin{abstract}
Summary
The author of this article discusses creative use of stereotype and a linguistic view of the world employing Hilary Putnam's definition of stereotype. Semantic stereotype is contained in the structure of language and it is one of the basic elements of the linguistic picture of the world, but paradoxically creative use of stereotype contradicts the system of beliefs, ideas and norms contained in the language. Creative use of stereotype is one of the ways of creating private linguistic view of the world. The author distinguishes three types of creative use of stereotype: contradiction, overstatement or accentuation and using of stereotype as a premise in order to draw absurd conclusions. Creative use of stereotype is one of the ironic linguistic devices. It may be used not only as means of presenting the linguistic view of the world, but also of reaching persuasive goals.
\end{abstract}

